\title{
Assessing the Impact of Floods Disaster on Soil Erosion Risk Based on the RUSLE-GloSEM Approach in Western Iran
}

Morteza Akbari ( $\sim$ m_akbari@um.ac.ir)

Ferdowsi University of Mashhad https://orcid.org/0000-0002-8637-266X

Ehsan Neamatollahi

Ferdowsi University of Mashhad

Hadi Memarian

University of Birjand

Mohammad Alizadeh Noughani

Ferdowsi University of Mashhad

\section{Research Article}

Keywords: Natural disasters, Human activities, Risk assessment, Land degradation, GloSEM

Posted Date: September 13th, 2021

DOI: https://doi.org/10.21203/rs.3.rs-775510/v1

License: (1) This work is licensed under a Creative Commons Attribution 4.0 International License. Read Full License 


\title{
Assessing the impact of floods disaster on soil erosion risk based on the RUSLE-GloSEM approach in western Iran
}

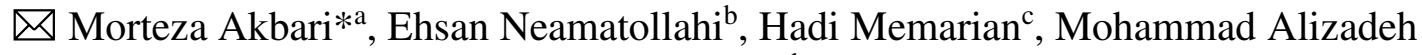 \\ Noughani ${ }^{d}$, \\ ${ }^{a}$ Department of Desert Areas Management, Faculty of Natural Resources and Environment, Ferdowsi University \\ of Mashhad, Mashhad, Iran. Email: m_akbari@um.ac.ir; desertology@gmail.com, (Corresponding Author) \\ ${ }^{\mathrm{b}}$ Legumes Department, Research Center for Plant Sciences, Ferdowsi University of Mashhad, Mashhad, Iran \\ ${ }^{\mathrm{c}}$ Land Resources Management (Soil Conservation Engineering), Department of Rangeland and Watershed \\ Management, Faculty of Natural Resources and Environment, University of Birjand, Birjand, Iran \\ ${ }^{\mathrm{d}}$ Department of Environmental Sciences, Faculty of Natural Resource and Environment, Ferdowsi University of \\ Mashhad, Mashhad, Iran.
}

\begin{abstract}
Floods cause great damage to ecosystems and are among the main agents of soil erosion. Given the importance of soils for the functioning of ecosystems and development and improvement of bio-economic conditions, the risk and rate of soil erosion was assessed using the RUSLE model in Iran's Lorestan province before and after a period of major floods in late 2018 and early 2019. Furthermore, soil erosion was calculated for current and future conditions based on the Global Soil Erosion Modeling Database (GloSEM). The results showed that agricultural development and land use change are the main causes of land degradation in the southern and central parts of the study area. The impact of floods was also significant since our evaluations showed that soil erosion increased from $4.12 \mathrm{t} \mathrm{ha}^{-1} \mathrm{yr}^{-1}$ before the floods to $10.93 \mathrm{t} \mathrm{ha}^{-1} \mathrm{yr}^{-1}$ afterwards. Field surveying using 64 ground control points determined that erodibility varies from 0.17 to $0.49 \%$ in the study area. Orchards, farms, rangelands and forests with moderate or low vegetation cover were the most vulnerable land uses to soil erosion. The GloSEM modeling results revealed that climate change is the main cause of change in the rate of soil erosion. Combined land use change-climate change simulation showed that soil erosion will increase considerably in the future under SSP1RCP2.6, SSP2-RCP4.5, and SSP5-RCP8.5 scenarios. In the study area, both natural factors, i.e. climate change and human factors such as agricultural development, population growth, and overgrazing are the main drivers of soil erosion.
\end{abstract}

Keywords Natural disasters . Human activities . Risk assessment . Land degradation . GloSEM

\section{Introduction}


Environmental change influences on the ecosystem through the variations in its components; therefore, natural disasters, which impact on and are impacted by environmental components, can be affected by environmental changes (Sholihah et al. 2020). While the damage caused by the most natural disasters is temporally immediate, floods often have more lasting consequences. Human settlements in close proximity to rivers are most susceptible to floods, particularly flash floods caused by torrential rainfall. The most common impacts of extreme floods are property damage and reduced crop yields. Additionally, floodwaters can become contaminated and consequently cause disease (Arnell and Gosling 2016; Adikari et al. 2009). Based on the reports by the Emergency Events Database (EM-DAT), maintained by the Centre for Research on the Epidemiology of Disasters (CRED), Asia is particularly vulnerable to natural disasters; in the period from 2000 to 2019, 7,348 major disaster events were recorded in Asia, claiming 1.23 million lives, affecting 4.2 billion people, and costing approximately \$2.97 trillion dollars in global economic (UNDRR, 2020; Adeel et al. 2020). More recently, climate change has also become a major factor that affects floods by concentrating total annual rainfall in increasingly sporadic and intense rainstorm events (Cramer et al. 2015). Floods can also cause damage to the environment through affecting components such as soil (Nepal et al. 2021).

Soil erosion is a complex process with direct and indirect socio-economic and environmental impacts, determined by the factors such as landform and geomorphology, physical and chemical properties of soil, hydrography, rainfall regime, land use, land cover, and land management practices (Imbrenda et al. 2014; Salvati et al. 2013). Although soil erosion is only one of the manifestations and aspects of land degradation, it can be considered the most critical aspect (Lal 2008). By reducing soil nutrients, soil erosion increases food production costs (Quinton et al. 2010; Brevik et al. 2020) and, as a result, it causes economic and environmental damage (Telles et al. 2011).

Soil erosion assessment has recently become a way to respond to environmental concerns, especially in industrialized countries (Nachtergaele 2004). Modern societies increasingly depend on cultivated lands, so that more than a third of the earth's land area being covered by agricultural lands (Foley et al. 2011). Ninety-five percent of global food production relies on the cultivation of plants and livestock, which is itself dependent on the capacity of soil to sustain living organisms (FAO 2015). In recent decades, the unbalanced development and expansion of agricultural lands have led to a significant increase in soil erosion, especially in developing countries (FAO 2015). Inattention to topography, texture and structure of the soil, and mismatch between soil and climatic conditions and the ecological needs of cultivated crops are among the most important causes of severe soil erosion in agricultural lands (Chandra pal et al. 2021). Therefore, attention is paid to two key issues in agricultural science to reduce soil erosion: first, land suitability is taken into consideration for crop selection and cultivation, and second, optimal cropping patterns are determined (Derakhshan-Babaei et al. 2021; Akbari et al. 2019). Human activities such as agricultural development, have been significant drivers of soil and environmental degradation in recent years (Montanarella 2015; Mueller et al. 2013; Zhang et al. 2016; Nga et al. 2018). The latest report by the Food and Agriculture Organization of the United Nations (FAO 2015) on the status of global soil resources highlights the worrying condition of the world's soil resources and stresses the threat of soil erosion to the environment on a global scale. The most significant anthropogenic drivers of soil erosion are land use change and climate change (O’Neal et al. 2005). While past works have shown more interest in soil erosion in arable lands, natural systems cannot be ignored (Boardman and Poesen 2006). However, assessment of soil erosion in natural lands has been limited due to the lack or absence of climatic and soil characteristics data on local and global measures (Bosco et al. 2015; Akbari et al. 2016b). In the long run, assessing soil erosion requires reliable long- 
term data, which is costly in terms of time and money (Salvati et al. 2013; Cox et al. 2018). In answer, semiempirical tactics have been established to incorporate existing knowledge with logical necessities with the target of generating results which can be utilized to inform policy (Borrelli et al. 2020). To estimate soil erosion in agricultural lands, models such as CREAMS, SLEMSA, GUESS, USLE, RMMF, and MUSLE have been developed, while others such as EUROSEM, RUSLE, WEPP, and CORINE have been created for rangelands and watersheds (Zakerinejad and Maerker 2015; Panagos et al. 2014; Prasanna kumar et al. 2011; Silva et al. 2012; Tsara et al. 2006; Aiello et al. 2015).

Today, risk-based management (as opposed to crisis management) is one of the proposed solutions to reduce the impact of uncertainties and losses (Ammann 2016; Akbari et al. 2016a). In this context, risk assessment allows the preparation of maps for potential and actual risk studies (Messner and Mayer 2005). The selection of a method for risk assessment is determined by the kind of considered risk, i.e. whether the risk is direct or indirect, and whether it is tangible or intangible (Penning-rowsell et al. 2005; Merz et al. 2010). Recent advances in remote sensing (RS) have made earth observation data more available and more accurate, and have expanded our data processing capabilities, ushering in an array of new indicators to capture important variables in erosion risk assessment such as vegetation (Liu et al. 2021). In this regard, the models that consider the impact of climate change and land use parameters through incorporating RS products can impressively assist us to evaluate the risk of soil erosion. The Global Soil Erosion Modeling Database (GloSEM) is based on the RUSLE model and offers a more comprehensive modeling framework for estimating future global soil erosion scenarios (Borrelli et al. 2020). From November 27, 2018, to April 12, 2019, Iran was affected by three strong weather systems which released unprecedented amounts of rain and caused extensive flooding in the west and southwest of Iran. Although flooding is not uncommon in this area and annually incurs damages to natural and man-made features, as well as claiming the lives of people and livestock, the occurred floods in this period were particularly destructive. In some cases, the extent of the damage was so great that the locally available facilities failed under the increased intensity of flooding. We assessed the soil erosion resulting from flooding in one of the regions that were most severely affected by the recent floods. We also used different climatic and land-use scenarios to predict soil erosion for current and future conditions in the study area based on the Global Soil Erosion Modeling Database (GloSEM). Moreover, flood damage was estimated to address the gap in the current knowledge about the current and future damage caused by soil erosion. Our findings provide policymakers with an evaluation of soil erosion and enable them to identify potential hotspots of soil erosion, which can be used to mitigate the negative impacts of erosion through collaboration with stakeholders.

\section{Material and methods}

\subsection{Study area}

Lorestan province is located in the west of Iran and has an area of $28064 \mathrm{~km}^{2}$ (8.1 percent of the total acreage of Iran). The province is located between $46^{\circ} 51^{\prime}$ and $50^{\circ} 01^{\prime} \mathrm{E}$, and $32^{\circ} 37^{\prime}$ and $37^{\circ} 34^{\prime} \mathrm{N}$. Based on the latest national census in 2015, the population of the province was 1760649 people; with the largest population belonging to Khorramabad county, and the smallest to Romeshkan county. Natural and agricultural land uses in the province are as follows: forests (43.34\%), rangelands (30.12\%), deserts (0.41\%), agricultural lands (18.57\%), and orchards (7.55\%) (Nabati et al. 2020). Over the past decade, there has been a significant increase in the acreage of cultivated lands in the province (Iranian Ministry of Agriculture statistical yearbook 2020). The province overlaps with the 
watersheds of two major rivers in Iran (Karkheh and Dez), and its geographical location and altitude have increased precipitation in the province in comparison with the neighboring provinces. Woodlands across the province have been under increased pressure as a result of exploitation for fuel and conversion into pastures. Grazing and human interventions have also negatively impacted the natural zones in the province. The province is susceptible to floods, especially since warm rainfall in April can accelerate the melting process of accumulated snow and consequently cause flooding (Sharafi and Noorollahi 2020). Data shows that 436 spots in the province are vulnerable to floods (Hydrological report, Regional Water Company of Lorestan Province 2019). Figure 1 shows the geographical location of the study area with flood-prone regions.

From November $27^{\text {th }} 2018$ to April $12^{\text {th }} 2019$, Lorestan province experienced five serious instances of flooding. The first flood occurred on 27 November 2018, the second on 4-5 December 2018, and the third on 7-8 February 2019. The high intensity and large volume (up to $80 \mathrm{~mm}$ ) of rainfall caused significant damages across the province, especially in Khorramabad and Poldakhtar counties. During 3-12 April 2019, two weather systems converged on the province, causing two major flooding events. During these floods, especially the second flood, most of the Poldakhtar county and parts of Khorramabad, Delfan, and Kuhdasht counties were flooded (Meteorological Report, General Meteorological Office of Lorestan Province 2019). It should be noted that Poldakhtar county is faced with the highest flooding risk in the province, and Khorramabad county, located at the outlet of the Karkheh watershed, has historically suffered severe damages due to floods (Hydrological report, Lorestan Regional Water Company 2019). The fourth flood happened on 4-5 April 2019, damaging many urban and rural residential and commercial units, as well as impacting infrastructures; the damage to roads (both main roads and rural roads) was especially severe. The fifth flood occurred on April $11^{\text {th }}$ and $12^{\text {th }}, 2019$, triggered by extreme precipitation (reaching $170 \mathrm{~mm}$ in some areas) and dealing substantial damage to the province's infrastructures including a large number of main routes, interurban and rural road structures, water supply lines, power lines, the telecommunication network, and even oil and petrochemical facilities (Lorestan Crisis Management Report 2019). Tables 1 and 2 summarize the characteristics of topography, meteorology, and hydrology for Lorestan province.

A warming climate and changing precipitation patterns in the study area have also contributed to more severe flooding as warm rainfall in spring leads to the melting of the snow accumulated in mountainous areas. The role of snow as a contributing factor to extreme hydrological events and natural hazards has been established in past research (Akbari et al. 2017).

\subsection{RUSLE model and data analysis}

In this study, soil erosion was evaluated using the Revised Universal Soil Loss Equation (RUSLE) model in Arc GIS 10.8. The revised version of the global soil erosion equation is used to evaluate and predict erosion, and to design conservation plans based on six factors (Eq.1).

$$
S E=R * K * L * S * C * P
$$


Where, $S E$ is average soil erosion per unit area $\left(\mathrm{t} \mathrm{ha}^{-1} \mathrm{y}^{-1}\right), R$ is erosivity factor (MJ mm ha $\left.\mathrm{m}^{-1} \mathrm{~h}^{-1} \mathrm{y}^{-1}\right), K$ denotes erodibility factor ( $\mathrm{t} \mathrm{ha} \mathrm{MJ}^{-1} \mathrm{~mm}^{-1}$ ), $L$ is slope length factor, $S$ defines slope steepness factor, $C$ stands cover management factor, and $P$ is supported practices factor (Note: L, S, C, P are dimensionless).

The flow diagram for calculating soil erosion before flooding (01/11/2017 to 30/04/2018) and after flooding (01/11/2018 to 30/04/2019) is depicted in Figure 2.

Information layers which were subject to change before and after flooding such as NDVI and erosivity (R) were calculated separately for each period. Other factors such as L, P and K were considered unchanged. Figure 3 shows the map of variables used in the RUSLE model.

\subsubsection{Rainfall erosivity (R)}

Rainfall is a major driving force of soil erosion since raindrops (through splash erosion), and runoff flow erode the surface. Rainfall erosivity factor (R) was presented by Wischmeier and Smith to capture the impact of climate on soil erosion (Wischmeier and Smith 1978). The yearly R-factor is computed based on the $\mathrm{EI}_{30}$, which is resulted from the complete and long-term records of storm kinetic energy (E) and maximum thirty-minute intensity (Morgan 2005; Renard et al. 1997). In this study, R was estimated based on the data from meteorological stations in the study area for the period before the floods (11/01/2017 to 30/04/2018) and the period the floods occurred in (11/01/2018 to 30/04/2019). The time intervals were selected to include the rainy season in the study area. The erosivity index in the RUSLE model is obtained from the average total erosion of rainfall events per year using Equation 2 (Arnoldus 1980).

$$
R=\sum_{j=1}^{12} 1.735 * 10\left(1.5 \log 10\left(\frac{p i 2}{p}\right)-0.08188\right)
$$

Where, $R$ is rainfall erosivity (MJ mm ha ${ }^{-1} \mathrm{~h}^{-1}$ year $^{-1}$ ), $P i$ is monthly rainfall (mm), and $P$ is annual rainfall (mm). Rainfall erosivity values were interpolated in ArcGIS 10.8 using kriging/cokriging technique.

\subsubsection{Soil erodibility $(\mathrm{K})$}

Soil erodibility $(\mathrm{K})$ reflects the inherent vulnerability of soils to water erosion, as reflected by the properties of the soil (Renard et al., 1997). K is the "average annual soil loss per unit of rainfall erosivity under a standard circumstance of bare soil under no conservation practice" (Morgan 2005). In the RUSLE model, Wischmeier and Smith (1978) and Renard et al. (1997) calculated K by means of a formula that involves soil texture and structure, organic matter content, and profile permeability.

The soils in the study area include inceptisols, vertisol, and entisols (Hydrological Report of Lorestan Regional Water Company 2019). Inceptisols form quickly through alteration of the parent material. They are more developed than entisols and have no accumulation of clays, iron oxide, aluminum oxide, or organic matter. Vertisols contain large amounts of expansive clays such as montmorillonite, which create deep cracks in the soil when dried. Entisols are not significantly different from their parent material and show no profile development, except an A horizon. Inceptisols, vertisols, and entisols are all very sensitive to erosion (USDA 1975).

The soil map of the study area (at 1:100,000 scale) was initially used to investigate soil erodibility. A field survey using 64 ground control points (GCPs) in different land units was then conducted to update the soil map. Soil 
erodibility was determined based on sand, clay, silt, and organic matter content. Table 3 shows the results of the soil survey. To convert soil erodiblity to metric units, the figures in Table 3 were multiplied by 0.1317 to give $\mathrm{K}$ in terms of $\mathrm{t} \mathrm{h} \mathrm{MJ} \mathrm{Mm}^{-1}$.

\subsubsection{Slope length (L)}

Slope length (L) affects sheet, rill, and inter-rill erosion (Wischmeier and Smith 1978). L is the horizontal distance from the upstream source of flow to the point where the slope changes significantly. Soil erosion increases with increasing slope length (Renard et al. 1997; Krishna Bahadur 2009). More advanced methods for topographically complex units employ approaches which incorporate contributing area and flow accumulation (Desmet and Govers 1996). A digital elevation model (DEM) provided by the Iran's National Cartographic Center was used to calculate slope length. The elevation model had a cell size of $30 \times 30 \mathrm{~m}$ and was prepared based on 1:50,000 topographic maps and 1:50,000 contour maps with a 20-m elevation difference between contour lines. The slope map was obtained using the spatial analyst toolbox in ArcGIS. To calculate L, Equation 3 was applied to the DEM (Moore \& Burch, 1986):

$$
L=(\text { FlowAccumulation } \times \text { CellSize } / 22.13)^{0.4}(\text { SinSlope } \times 0.0896)^{1.3}
$$

Where, $L$ is slope length, flow accumulation is the accumulated slope area contributing to flow in a given cell, and SineSlope is slope in degree.

\subsubsection{Cover management (C)}

A comprehensive scientific approach to the study of land degradation processes, especially soil erosion, should use remote sensing and satellite imagery to capture different cover management practices. Advances in remote sensing and data processing and increased access to data have made a way for new vegetation indices and remote sensing products with better resolution and accuracy (Fu et al. 2021; Nabati et al. 2020). The cover management factor $(\mathrm{C})$ is the ratio of the amount of soil lost from cultivated land to the amount of soil lost from the same land under continuous fallow without vegetation (El Jazouli et al. 2017). Vegetation cover is considered the second major factor (after topography) controlling soil erosion. An increase in C leads to an increase in exposed soil and thus an increase in potential soil loss (El Garouani et al. 2008). C is calculated using empirical equations based on field measurements of ground cover (Wischmeier and Smith 1978). The most appropriate method for determining vegetation cover is to employ the normalized vegetation difference index (NDVI), which is obtained using satellite imagery (Renard et al., 1997). NDVI is an indicator of the energy reflected by the earth (Kouli et al. 2009), and ranges between -1 and +1 . In this study, using Sentinel- 2 images and a mosaic of 9 frames, the average NDVI was calculated for the period before and after the floods (11/01/2017 to 30/04/2018 and 11/01/2018 to 30/04/2019, respectively) according to Equation 4:

$$
N D V I=(N I R-I R) /(N I R+I R)
$$

Where, NIR is the near-infrared band, and $I R$ is the red optical band. 
Due to the Mediterranean climate of Iran, most of the rainfall occurs in autumn and winter; therefore, the formula presented by Lin et al. (2002) provides a more appropriate estimate of the status of vegetation. In this method, C is obtained based on the following equation (Eq. 5):

$$
C=\exp \left[-\alpha \frac{N D V I}{(\beta-N D V I)}\right]
$$

Where, $\alpha$ and $\beta$ are dimensionless parameters, and NDVI is the normalized difference vegetation index.

Sentinel-2 is an earth observation project developed by the European Space Agency as part of the Copernicus program and includes two identical satellites (Sentinel-2E and Sentinel-2B). Sentinel 2B is capable of multispectral imaging in 13 bands including the visible, near-infrared, and short-wave infrared spectra. Images are recorded at 5-day intervals and are available to the public for free. In this research, images captured by Sentinel 2B on April 30th, 2018, and April 30th, 2019 were used. The list of images is presented in Table 4.

\subsubsection{Support practice $(\mathrm{P})$}

Support practices or conservation practices $(\mathrm{P})$ is calculated as the ratio of soil loss after implementation of support practices to soil loss in the absence of support practices (Renard et al. 1997). In the past decade, the area of agricultural lands in the Lorestan province has increased remarkably, increasing from $3.2 \%$ of total national agricultural land in 2011 to 4.7\% in 2020 (Iranian Ministry of Agriculture statistical yearbook 2020). In large areas such as our study area, $\mathrm{P}$ is estimated based on slope since areas with similar slope often experience the same level of protection from erosion. Accordingly, we used the table provided by Wischmeier and Smith (1978) to derive $P$.

\subsection{Prediction of the combined impacts of climate and land use changes on soil erosion}

The Global Soil Erosion Modelling Database (GloSEM) has been developed based on the RUSLE model to provide a more comprehensive framework for global assessment of soil erosion under different scenarios (Borrelli et al. 2020). This database uses the latest climate change and land use change scenarios (SSP-RCP, Shared Socioeconomic Pathway-Representative Concentration Pathway) to simulate erosion in the future. The GloSEM takes advantage of the land use change scenarios for 2070 extracted from the Land Use Harmonization project and the climate change scenarios developed by the European Union's Joint Research Centre. In this database, uncertainties in predictions are assessed and validated using Monte Carlo-Markov Chain (MCMC) methods. The impacts of climate change on rainfall erosivity (R) are considered under RCP2.6, RCP4.5, and RCP8.5, and the impacts of land use change on support practices $(\mathrm{P})$ and cover management $(\mathrm{C})$ are considered under SSP1-RCP2.6, SSP2RCP4.5, and SSP5-RCP8.5. The combined effects of changes in R, P, and C under global change scenarios are then investigated in the framework of the RUSLE model. Research shows that even under the most optimistic scenario (SSP1-RCP2.6), global soil erosion can increase by up to $30 \%$.

In the SPP1 scenario, the world is on a trajectory which consistently moves in a sustainable direction, without causing pollution or environmental degradation. In this scenario, land use is highly regulated and controlled; for instance, deforestation in the tropics is significantly reduced. In the low- and middle-income regions, crop yields are rapidly rising, which leads to accelerated development in high-income countries, and healthy diets with a small 
proportion of animal products and minimum waste become widespread. This scenario envisions a future where food is traded on an international level, and international collaboration against climate change begins early (after 2020); pollutants are also priced according to the price of carbon in the energy sector. In the SPP2 scenario, historical social, economic, and technological trends hold in the future. Land use change is not regulated and deforestation continues in the tropics. In this scenario, an international collaboration to control climate change is delayed until 2040 due to the transition to a unified carbon price; during this transition, emissions from agricultural production are priced on the same level as emissions from the energy sector, while at the same time, deforestation is not prevented and afforestation is not encouraged. In the SPP5 scenario, the world sees increased faith in competitive markets, innovation and collaboration for rapid development of technology and human capital under the guidance of emerging industrial economies as the means to sustainable development. Land use change is unregulated and unplanned, meaning deforestation continues in the tropics although its rate might slow down in later years (Poop et al. 2017; Memarian and Akbari 2021). In this study, we compared the predictions made by GloSEM with our regional evaluation of soil erosion in Lorestan province.

\section{Results and discussion}

RUSLE applications usually estimate soil loss at the annual timescale (Renard et al., 1997; Sadeghi et al., 2014), as a result, our findings are reported per year despite the selected periods being shorter. The data layers (maps) extracted for R, K, L, C, and P were integrated using the raster calculator in ArcGIS 10.8 to quantify, evaluate, and generate the maps of soil erosion risk and severity for the Lorestan province. The values of R, K, L, C, and P are shown in Table 6.

\subsection{Impact of rainfall erosivity on soil erosion}

Although various factors are involved in increasing the intensity of soil erosion, the variation in climatic parameters due to climate change has come to play a very important role in recent years (Borrelli et al. 2020). Meteorological data for the region showed that the average R-factor for the period before and after flooding was 58.87 and 157.6 $\mathrm{MJ} \mathrm{mm} \mathrm{ha}{ }^{-1} \mathrm{~h}^{-1} \mathrm{y}^{-1}$, respectively. Rainfall intensity, duration, and frequency are the main determinants of runoff generation. All three factors were extremely high for the precipitation that occurred in Lorestan province, especially on April 12, 2019.

Maps obtained from the analysis of meteorological data showed that the highest value of $\mathrm{R}$ belonged to the southern parts of the province such as Poldakhtar county and the northern and western parts of such as Dorud, Khorramabad, and Delfan counties (see Fig. 2). Official reports by the local departments and organizations also confirm this finding (Meteorological Report, General Meteorological Office of Lorestan Province 2019). These areas are high-risk flood zones because of severe land use changes (such as Poldokhtar) or due to being located in mountainous terrain (such as Dorud, Khorramabad, and Delfan).

Before the recent episode of flooding, snow had covered the heights of the region. Following an increase in air temperature and rainfall, the accumulated snow melted, which intensified the floods. In addition, due to the large amount of rainfall on April 12th, 2019, soils were almost saturated, which reduced the infiltration rate and increased runoff generation (Meteorological Report, General Meteorological Office of Lorestan Province 2019). Table 7 shows the $\mathrm{R}$ values for meteorological stations in the study area. 
Soil erodibility was obtained based on the percentage of clay, silt, sand, and organic matter in the soil profile based on soil map and the data collected at 64 ground control points (Table 3). The results show that erodibility varies from 0.17 to 0.49 . The highest figures were observed in orchards, agricultural lands (i.e. rainfed agricultural lands in the southern parts of the region), and rangelands and forests with moderate and low vegetation cover (i.e. piedmont plains of the central region and the western canal). Khorramdareh county, with the largest area of rainfed and irrigated arable lands, and Poldakhtar county with the largest area of rangelands and forests with moderate and low vegetation cover, face the highest rates of erosion. According to the available official reports, soil salinity is more severe in Poldakhtar county, compared to other counties; the droughts in recent decades have also increased salinity (Akbari et al. 2016a). Increased soil salinity has reduced permeability and increased erosion during floods. The cities of Khorramabad, Delfan, and Selseleh in the northern and central parts of the study area have highly erodible soils due to extensive dryland agriculture. Mountainous lands in the eastern and northern parts are less erodible due to their dense forest cover. Overall, the results showed that human activities and natural factors such as extensive and continuous drought along with erosion-sensitive soils have increased erodibility. Long-term drought has also increased rainfall erosivity in the area. According to a report by the General Meteorological Office of Lorestan Province (2019) using standardized precipitation-evapotranspiration index (SPEI), about $78 \%$ of the province has experienced moderate to severe drought; while central counties have been less affected (e.g. Selseleh county with only $5 \%$ of its area being affected), those in the southern, northern, and eastern parts of the region have been severely impacted (e.g. Poldakhtar county, with $99 \%$ of its area affected).

\subsection{Impact of topography on soil erosion} About $71 \%$ of the study area is mountainous and has a slope higher than $25 \%$. This steep mountainous topography has played an important role in shortening the time of concentration of runoff (Tc) and flood generation. In addition, the prevalence of fine-grained and impermeable formations in the region will produce large amounts of runoff after each rainfall (Lorestan Crisis Management Report 2019). The study area has an altitude between 188 to $4000 \mathrm{~m}$ above sea level. High and mountainous areas are generally located in the northern and eastern parts and piedmont plains and lowland areas in the southern and western parts. The slope map also showed variations in slope ranging from 1 to $48 \%$. The average slope of the region is about $19 \%$, which indicates that the region is mountainous.

Under rainy conditions, steep slopes are prone to landslides and increased soil erosion. The value of the slope length factor (L) varied from 0 to 0.27 . These figures are consistent with the changes in the elevation and slope of the area. It should be noted that despite their gentle slope, mildly sloped and flat regions experience more erosion because soils are deeper in such areas, and therefore there is larger extent of soils that can be eroded. On steep slopes, however, what little soil exists is quickly eroded, i.e. the amount of soil is the limiting factor for how much erosion occurs, although potential erosion might be higher compared to flatter areas. The results obtained from studies of the Imbrenda et al. (2014) and Salvati et al. (2013) indicate the importance of topography in the severity of soil erosion. So that, increasing the slope in lands with low vegetation density has increased the severity of soil erosion. 
Nabati et al. (2020) utilized climatic, soil, and topographic variables to determine suitable areas for agriculture in Lorestan province. They found that only $19.88 \%$ of the province is suitable for irrigated agriculture and $54.2 \%$ for rainfed agriculture. NDVI was calculated based on the analysis of Sentinel-2B satellite images for the period before and after the flood. The results showed that vegetation cover was moderate in the eastern and northern parts (mountainous areas with moderate density pastures and forests) and low in the western and southern parts (lowdensity pastures with seasonal agricultural ands). Vegetation cover, along with slope angle and length, is the major important determinant of soil erosion and sediment production (FAO 2015; El Jazouli et al. 2017). The large value of the cover management factor (C) in the study area indicates a high risk of soil erosion. The map obtained for the support practices factor $(\mathrm{P})$ showed that the highest values belong to areas with steep slopes. In the study area, $\mathrm{P}$ varied from 0.5 to 1 , with the lower values associated with the southern parts such as Poldakhtar, Dasht mountain, Delfan, and Selseleh, which are mostly located on plains and foothills.

\subsection{Spatial distribution of soil erosion}

Analysis of the spatial distribution of soil erosion showed that the southern parts (such as Poldakhtar) and central and eastern parts (such as Khorramabad and Aligudarz) experienced significant soil erosion. The map obtained from the combination of different soil erosion factors in the RUSLE model (Fig. 4) showed that the study area was affected by different factors before and after the floods, but changes in climatic parameters played an important role in both periods. According to the available reports and field studies, agricultural development and land use changes are the main causes of land degradation in the southern and central parts of the study area (Memarian and Akbari 2021; Derakhshan-Babaei et al. 2021; Nga et al. 2018).

We also found that the floods occuring between 01/11/2018 and 30/04/2019 substantially increased soil erosion. Soil erosion rate in the pre-flood period was $4.12 \mathrm{t} \mathrm{ha}^{-1} \mathrm{yr}^{-1}$, but increased to $10.93 \mathrm{t} \mathrm{ha}^{-1} \mathrm{yr}^{-1}$ after the floods (Table 8). While the majority of the study area experienced low to moderate erosion before the floods, more than a third (about 36\%) of the study area faced moderate to high erosion post-flood. These results are consistent with that of Kramer et al. (2015) on the impact of climate change on soil erosion. According to the FAO report (2015) both natural factors such as climate change, and anthropogenic factors such as agricultural development, population growth, and overgrazing intensify erosion. The pre-flood and post-flood periods in our study area clearly show the effects of both categories of factors on causing and intensifying erosion.

\subsection{Predicting future soil erosion based on GloSEM database}

The projections provided by the GloSEM were used to predict future soil erosion in the study area using the RUSLE model. The predictions showed minor deviations from the figures published by the European Union and USDA, indicating the accuracy of our predictions. This agreement also shows that the global estimations available from GloSEM are reliable and valid predictions on the regional scale.

410 Our results showed that land use changes in the southern and eastern parts of the study area will lead to reduced organic matter content, reduced soil quality, and change the physical and chemical properties of the soil. Along with increased erosivity of rainfall, these factors will increase soil erosion in the area. The models created for future conditions show that climatic changes are the main drivers of the increase in soil erosion. Combined land 
use change-climate change simulation indicates significant soil erosion under SSP1-RCP 2.6, SSP2-RCP4.5, and SSP5-RCP8.5 scenarios (Table 9). Although future changes in land use can impact soil erosion by changing the area of agricultural lands in either direction, the fact that the global climate is moving towards more extreme events suggests that soil erosion will become more severe in the future. The results show that when the combined effects of land use change and climate change are taken into account, soil erosion will have an increasing trend across the entire study area under SSP1-RCP2.6, SSP2-RCP4.5, and SSP5-RCP8.5, with over 80\% of the study area falling into moderate to very high classes of soil erosion. A comparison of the scenarios showed that although land use change can impact global soil erosion (especially through increasing or decreasing the area of agricultural lands), the shift in global climate toward more extreme hydrological cycles will act as the main driver of the increase in soil erosion. However, land management and environmental policymakers will be highly impactful on soil erosion as well. Despite the considerable soil erosion during flooding, these conditions will evolve into an environmental catastrophe by 2100 according to land use change and climate change scenarios (Popp et al. 2017; Memarian and Akbari 2021).

\section{Conclusion}

Although various factors are involved in increasing the intensity of soil erosion, change in climatic parameters, mainly due to climate change, plays a very important role. In our study area, rainfall erosivity caused significant damage both before and after the floods (01/11/2017 to 30/04/2018 and 01/11/2018 to 30/04/2019, respectively). The highest amount of rainfall erosivity belonged to the southern parts of the study area such as Poldakhtar county (mainly due to land-use change) and the northern and western parts such as Dorud, Khorramabad, and Delfan counties (due to mountainous terrain). These areas constitute the high-risk flood zones in Lorestan province. Before the recent episode of flooding, snow had covered the heights of the region. Following an increase in air temperature and rainfall, the accumulated snow melted, which intensified the floods. In addition, due to the large amount of rainfall on April 12th, 2019, soils were almost saturated, which reduced the infiltration rate and increased runoff generation.

Beside that, continuous and long-term droughts in the study area have also contributed to erosion. About $78 \%$ of the province has experienced moderate to severe droughts although central areas have suffered less severe erosion compared to the rest of the study area. Erosion was most severe in orchards, agricultural lands, and rangelands and forests with moderate or low vegetation cover. Khorramdareh county, with the largest area of rainfed and irrigated farms, and Poldakhtar county with the largest area of rangelands and forests, faced the highest rates of erosion. Due to the continuous drought in the study area during the past years, vegetation cover has declined across the province, depriving soils of protection against water erosion. So that, soil salinity is more severe in Poldakhtar county, compared to other counties; the droughts in recent decades have also increased salinity and this factor has reduced permeability and increased erosion during floods. Analysis of the spatial distribution of soil erosion showed that the southern parts (such as Poldakhtar) and central and eastern parts (such as Khorramabad and Aligudarz) have experienced significant erosion before and after floods. So that, both natural factors such as climate change, and anthropogenic factors such as agricultural development, population growth, and overgrazing intensify erosion. The pre-flood and post-flood periods in our study area clearly show the effects of both categories of factors on causing and intensifying erosion. The results obtained indicate the importance of topography in the severity of soil erosion. So that, increasing the slope in lands with low vegetation density has increased the severity 
of soil erosion. Beside that, our results showed that land use changes in the southern and eastern parts of the study area will lead to reduced organic matter content, reduced soil quality, and change the physical and chemical properties of the soil. Along with increased erosivity of rainfall, these factors will increase soil erosion in the area. The models created for future conditions show that climatic changes are the main drivers of the increase in soil erosion. Combined land use change-climate change simulation indicates significant soil erosion under SSP1-RCP 2.6, SSP2-RCP4.5, and SSP5-RCP8.5 scenarios.

In general, it should be noted in the RUSLE model have been applied a wide variety of indices and factors. Then, future research should focus on fine-tuning these models to better represent real-world conditions. Future works should augment previous studies by including other types of erosion, estimating erosion at shorter time scales, and improving the accuracy of the equations used to estimate erosion.

\section{Compliance with Ethical Standards}

This manuscript describes original work and is not under consideration for any other journal publication. This submission does not infringe upon any copyright. It does not contain any infringing, libelous, obscene, or other unlawful matter. The exclusive publication rights are conveyed to the publisher.

\section{Declaration of competing interest}

The authors declare that they have no known competing financial interests or personal relationships that could have appeared to influence the work reported in this paper.

\section{Acknowledgments}

This study was supported by the Faculty of Natural Resources and Environment at the Ferdowsi University of Mashhad in Iran under Grant No. 50654. Therefore, we thank all those who have helped us in the process. The authors are grateful to the anonymous reviewers for their insightful and helpful comments to improve the manuscript.

\section{References}

Adeel Z, Alarcón AM, Bakkensen L, Franco E, Garfin GM, et al. (2020) Developing a comprehensive methodology for evaluating economic impacts of floods in Canada, Mexico and the United States. Int J Disaster Risk Reduct. 50: 101861. https://doi.org/10.1016/j.ijdrr.2020.101861

Adikari Y, Yoshitani J (2009) Global Trends in Water-Related Disasters: An Insight for Policymakers-The United Nations World Water Assessment Programme; The United Nations Educational, Scientific and Cultural Organization: Paris, France.

Aiello A, Adamo M, Canora F (2015) Remote sensing and GIS to assess soil erosion with RUSLE3D and USPED at river basin scale in southern Italy. CATENA. 131: 174-185. http://dx.doi.org/10.1016/j.catena.2015.04.003

Akbari M, Ownegh M, Asgari H, Sadoddin A, Khosravi H (2016a). Desertification Risk Assessment and Management Program. Glob J Environ Sci Manag. 2(4): 365-380. https://doi.org/10.22034/gjesm.2016.02.04.006

Akbari M, Ownegh M, Asgari H, Sadoddin A, Khosravi H (2016b) Soil Erosion Risk Assessment Using the CORINE Model (Case Study: Semi-Arid Region in Golestan Province). J Desert Eco Eng. 12: 63-78

Akbari M, Ranaee E, Mirzakhan H, Dargahi A, Jargeh M (2017) Simulation of Snowmelt Runoff Using SRM Model and Comparison With Neural Networks ANN and ANFIS (Case Study; Kardeh dam basin). J Water and Soil. 30(6): 1794-1807 
Akbari M, Neamatollahi E, Neamatollahi P (2019) Evaluating land suitability for spatial planning in arid regions of eastern Iran using fuzzy logic and multi-criteria analysis. Ecol Indic. 98: 587-598. https://doi.org/10.1016/j.ecolind.2018.11.035

Ammann W (2016) Early warning in Disaster risk reduction- Needs and potential. 7thinternational conference on integrated natural disaster management- INDM. 15-16 Feb., Tehran-IRAN.

Arnoldus HMJ (1980) An approximation of the rainfall factor in the universal soil loss equation. In: De Boodt M, Gabriels D (eds) Assessment of erosion.Wiley, Chichester, pp 127-132 at a regional scale using GIS. Ekológia (Bratislava). 21: 404-422

Arnell NW, Gosling SN (2016) The impacts of climate change on river flood risk at the global scale. Clim. Chang. 134: 387-401

Boardman J, Poesen J (2006) Soil Erosion in Europe, (John Wiley \& Sons, 2006).

Borrelli P, Robinson DA, Panagos P, Lugato E, Yang JE, Alewell et al. (2020) Land use and climate change impacts on global soil erosion by water (2015-2070). Proc Nat Acad Sci. 117(36): 21994-22001

Bosco C, De Rigo D, Dewitte O, Poesen J, Panagos,P (2015) Modeling soil erosion at European scale: towards harmonization and reproducibility. Nat Hazards Earth Syst Sci. 15: 225-245. https://doi.org/10.5194/nhess$15-225-2015$.

Brevik EC, Slaughter L, Singh BR, Steffan JJ, Collier D, Barnhart P, Pereira P (2020) Soil and Human Health: Current Status and Future Needs Show less, Air, Soil and Water Research. 13: 1-23. https://doi.org/10.1177/1178622120934441

Chandra Pal S, Chakraborttt R, Roy P, Chowdhuri I, Das B, Saha A, Shit M (2021) Changing climate and land use of $21 \mathrm{st}$ century influences soil erosion in India. Gondwana Res. 94: 164-185. https://doi.org/10.1016/j.gr.2021.02.021.

Cramer W, Yohe GW, Auffhammer M, Huggel C, Molau U, Da Silva Dias MAF, Solow A, Stone DA, Tibig L, Leemans R. et al. (2014) Detection and attribution of observed impacts. Clim. Chang. 2014 Impacts Adapt. Vulnerability Part A Glob. Sect. Asp. 979-1038. Available online: https://www.zora.uzh.ch/id/eprint/105700/1/2014_HuggelC_WGIIAR5-Chap18_FINAL\%20.pdf (accessed on 16 June 2020).

Cox C, Jin L, Ganjegunte G, Borrok D, Lougheed V, Ma L (2018) Soil quality changes due to flood irrigation in agricultural fields along the Rio Grande in western Texas. Appl Geochem. 90: 87-100.

Derakhshan-Babaei F, Nosrati K, Ahmadi Mirghaed F, Egli M (2021) The interrelation between landform, land-use, erosion and soil quality in the Kan catchment of the Tehran province, central Iran. CATENA. 204: 105412. https://doi.org/10.1016/j.catena.2021.105412.

Desmet PJ, Govers G (1996) A GIS procedure for automatically calculating the USLE LS factor on topographically complex landscape units. J Soil and Water Conserv. 427-433.

El Garouani A, Chen H, Lewis L, Tribak A, Ab-harour M (2008) Cartographie de l'utilisation du sol et de l'érosion nette a partir d'images satellitaires et du SIG idrisi au nord-est du Maroc. Editions scientifiques GB. 8(3):193-201

El Jazouli A, Barakat A, Ghafiri A, El Moutaki S, Ettaqy A (2017) Soil erosion modeled with USLE, GIS, and remote sensing: a case study of Ikkour watershed in Middle Atlas (Morocco). Geosci Lett. 4:25. https://doi.org/10.1186/s40562-017-0091-6

FAO (2015) Healthy Soils Are the Basis for Healthy Food Production (Food and Agriculture Organization of the United Nations [FAO], 2015), pp. 1-4. http://www.fao.org/documents/card/en/c/645883cd-ba28-4b16a7b8-34babbb3c505/. Accessed 11 August 2020

Foley JA et al. (2011) Solutions for a cultivated planet. Nature. 478: 337-342

Fu A, Cai Y, Sun T, Li F (2021) Estimating the Impact of Land Cover Change on Soil Erosion Using Remote Sensing and GIS Data by USLE Model and Scenario Design. Sci Program. 6633428. https://doi.org/10.1155/2021/6633428

Krishna Bahadur KC (2009). Mapping soil erosion susceptibility using remote sensing and GIS: a case of the Upper Nam Wa Watershed, Nan Province, Thailand Environ Geol. 57: 695-705 
LAL R (2008) Land Degradation and Pedological Processes in a Changing Climate. Carbon Management and Sequestration Center, the Ohio State University, Columbus, OH 43210.

Lin C, Lin W, Chou W (2002) Soil erosion prediction and sediment yield estimation: the Taiwan experience. Soil and Tillage Res. 68: 143-152.

Liu L, Zhang X, Gao Y, Chen X, Shuai X, Mi J (2021) Finer-Resolution Mapping of Global Land Cover: Recent Developments, Consistency Analysis, and Prospects, J Remote Sens. 38: 5289697. https://doi.org/10.34133/2021/5289697

Merz B, Kreibich H, Schwarze R, Thieken A (2010) Assessment of economic flood damage. Nat. Hazards Earth Syst. Sci. 10:1697-1724

Messner F Mayer V (2005) Flood damage, vulnerability and risk perception challenges for flood damage research. UFZ, Leipzig, (pp26.).

Memarian H, Akbari. M (2021) Prediction of combined effect of climate and land use changes on soil erosion in Iran using GloSEM data. Iranian j Ecohydrol. 8(2), 513-534. doi: 10.22059/ije.2021.320754.1482

Montanarella L (2015) Agricultural policy: Govern our soils. Nature. 528: 32-33

Moore ID, Burch GJ (1986) Physical basis of the length slope factor in the Universal Soil Loss Equation. Soil Sci Soc Am j. 50(5): 1294-1298

Morgan RPC (2005) Soil Erosion and Conservation. National Soil Resources Institute, Cranfield University. http://doi.org/10.1002/9781118351475.ch22, 2005.

Mueller ND. et al. (2013) Corrigendum: Closing yield gaps through nutrient and water management. Nature. 494: 390

Nabati J, Nezami A, Neamatollahi E, Akbari M (2020) GIS-based agro-ecological zoning for crop suitability using fuzzy inference system in semi-arid regions. Ecol Indic. 117: 106646. https://doi.org/10.1016/j.ecolind.2020.106646.

Nachtergaele FO (2004) Land Degradation Assessment Indicators and the LADA project, Land and Water development Division, FAO, Italy.

Nepal S, Tripathi S, Adhikari H (2021) Geospatial approach to the risk assessment of climate-induced disasters (drought and erosion) and impacts on out-migration in Nepal. Inte J Disaster Risk Reduct. 59: 102241. https://doi.org/10.1016/j.ijdrr.2021.102241

Nga PH, Takara K, Van NC (2018) Integrated approach to analyze the total flood risk for agriculture: The significance of intangible damages-A case study in Central Vietnam. Inte J Disaster Risk Reduct. 31:862872.

O’Neal MR, Nearing MA, Vining RC, Southworth J, Pfeifer RA (2005) Climate change impacts on soil erosion in Midwest United States with changes in crop management. CATENA. 61: 165-184

Panagos P, Meusburger K, Marc VL, Alewell C, Hiederer R, Montanarella L (2014) Assessing soil erosionin Europe based on data collected through a European network. Soil Sci Plant Nutr. 60: 15-29. https://doi.org/10.1080/00380768.2013.835701

Penning-rowsell E, Johnson C (2005) Tunstall, S.; Morris, J.; Chatterton, J.; Green, C.; Koussela, K.; Fernandez-bilbao, A. The Benefits of Flood and Coastal Risk Management: A Handbook of Assessment Techniques; Middlesex University Press: London, UK, 2005; ISBN 1904750516

Popp A, Calvin K, Fujimori S, Havlik P, Humpenöder F, Stehfest et al. (2017) Land-use futures in the shared socio-economic pathways. Glob Environ Change. 42: 331-345.

Quinton JN, Govers G, Van Oost K, Bardgett RD (2010) The impact of agricultural soil erosion on biogeochemical cycling. Nat Geosci. 3: 311-314. https://doi.org/10.1038/ngeo838

Renard K, Foster G, Weesies G, McCool D, Yoder D (1997) Predicting soil erosion by water: a guide to conservation planning with the Revised Universal Soil Loss Equation (RUSLE). Agricultural Handbook. No. 703. http://doi.org/DC0-16-048938-5 65-100, 1997.

Sadeghi SH, Gholami L, Khaledi Darvishan A, Saeidi P (2014) A review of the application of the MUSLE model worldwide. Hydrol Sci J. 59(2): 365-375. http://doi.org/10.1080/02626667.2013.866239, 2014. 
Salvati L (2013) Map of long-term changes in land sensitivity to degradation of Italy. J Maps. 10: 6572. https://doi.org/10.1080/17445647.2013.842506

Sharafi S, Noorollahi D (2020) Assessing the Agricultural Land Use Potential in National Lands Using Spatial Planning Approach: The Case Study of Chalancholan Basin, East of Lorestan Province. Town and country planning. 12(2): 331-357. 10.22059/jtcp.2020.304873.670128

Silva RM, Montenegro SM, Santos CA (2012) Integration of GIS and remote sensing for estimation of soil loss and prioritization of critical sub-catchments-a case study of Tapacura catchment. Nat Hazards. 62: 953-970. https://doi.org/10.1007/s11069-012-0128-2

Soil Taxonomy (1975) A Basic System of Soil Classification for Making and Interpreting Soil Surveys, USDASCS Agric. Handbook, No. 436. (U. S. Gov. Print. Office, Washington, DC, 1975).

Iranian ministry of agriculture statistical yearbook (2020) Statistics of changes in land cultivation in Lorestan province.

Telles TS, Guimarães M, Dechen SC (2011) The costs of soil erosion. Rev Bras Cienc Solo. 35: 287-298

Tsara M, Kosmas C, Kirkby MJ, Kosma D, Yassoglou N (2006) An evaluation of the PESERA soil erosion model and its application to a case study in Zakynthos, Greece. Soil Use Manag. 21: 377385. https://doi.org/10.1079/SUM2005322

Wischmeier WH, Smith DD (1978) Predicting rainfall erosion losses. Agriculture Handbook. No. 537: 5 (537), 285-291. http://doi.org/10.1029/TR039i002p00285,

Zhang Q, Gu X, Singh VP, Liu L, Kong D (2016) Flood-induced agricultural loss across China and impacts from climate indices. Glob Planet Change. 139: 31-43. 
Figures

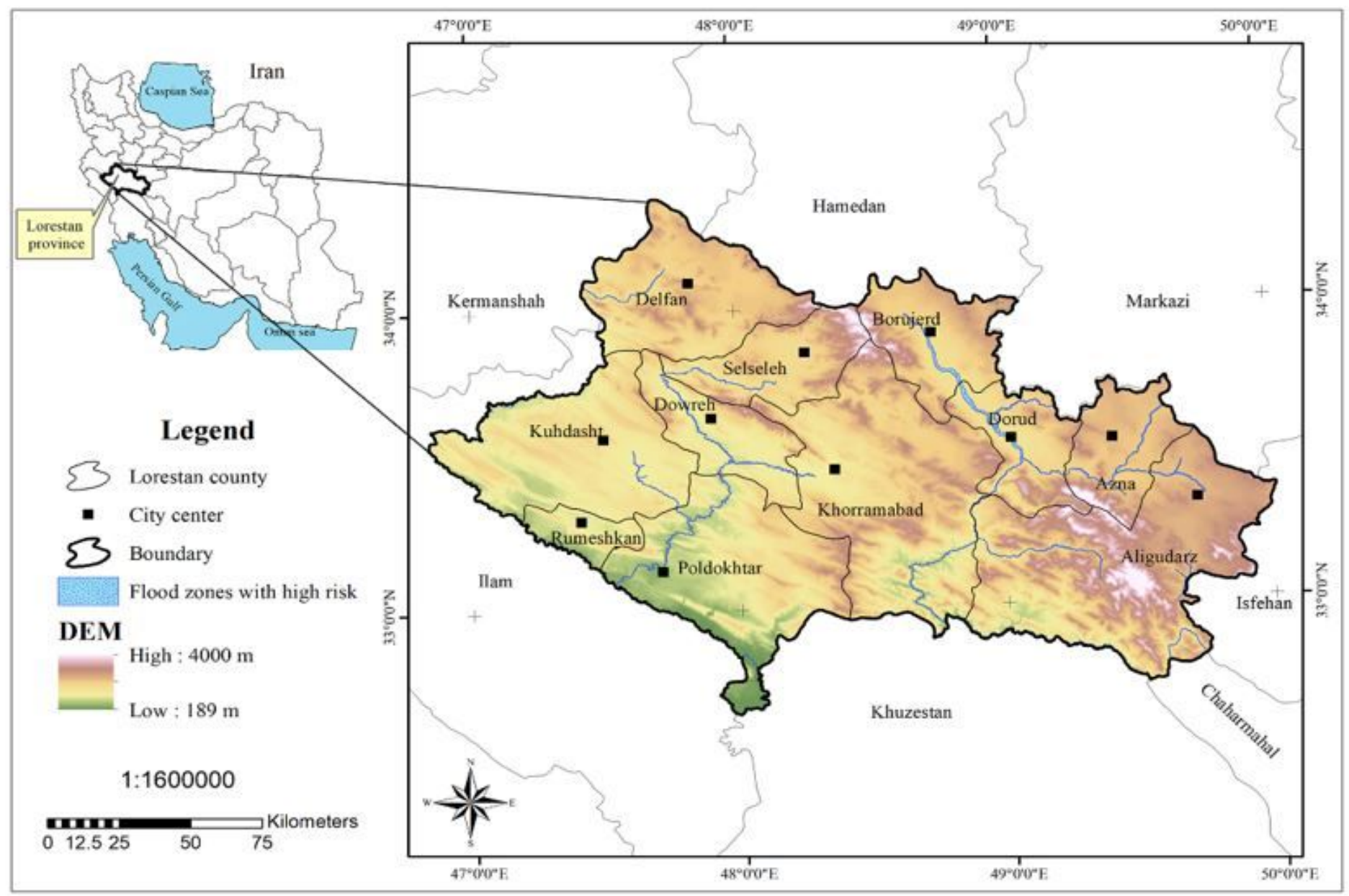

Figure 1

The geographic location of the study area and flood-prone regions 


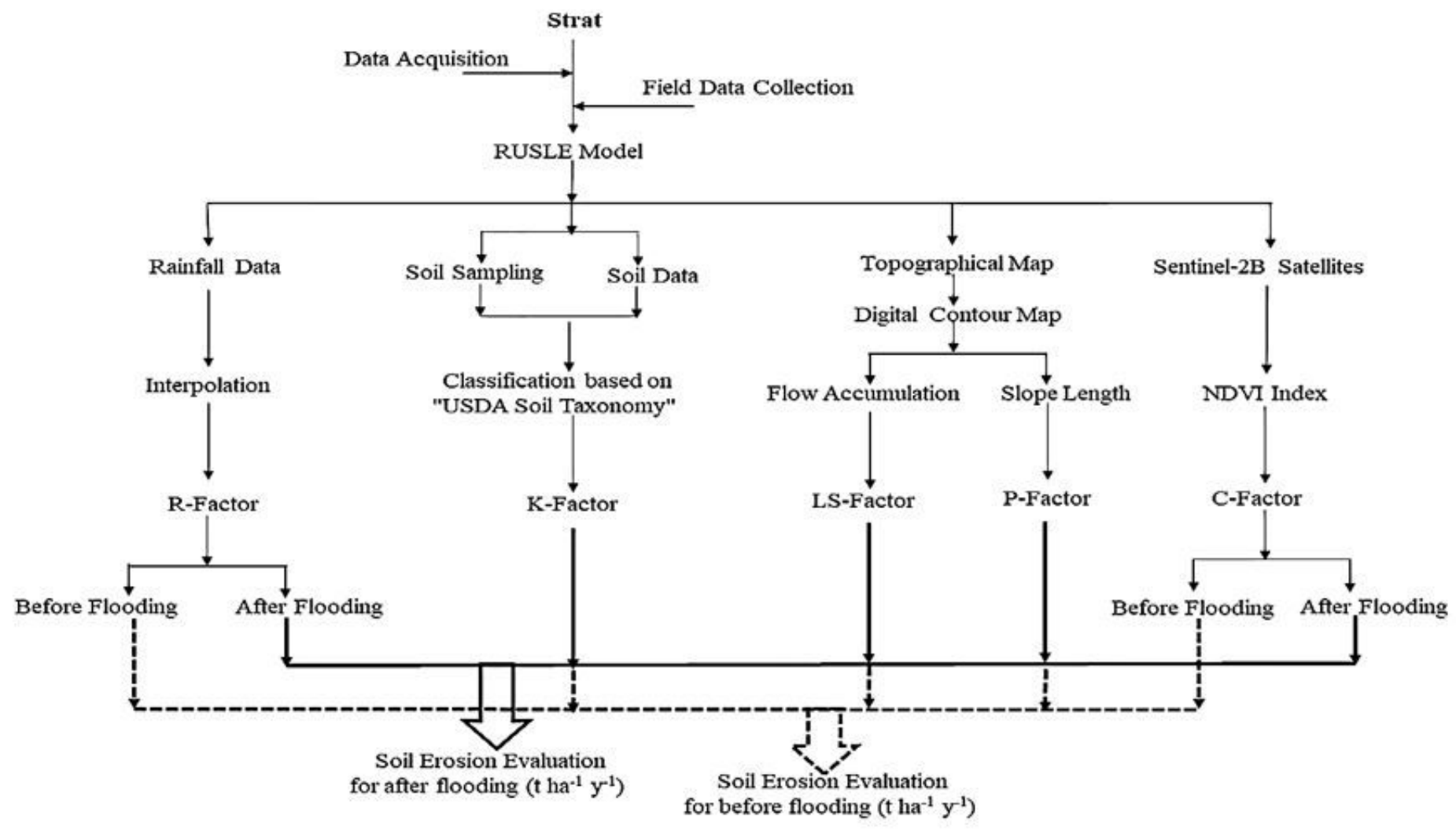

Figure 2

The flowchart for calculating soil erosion before and after flooding 


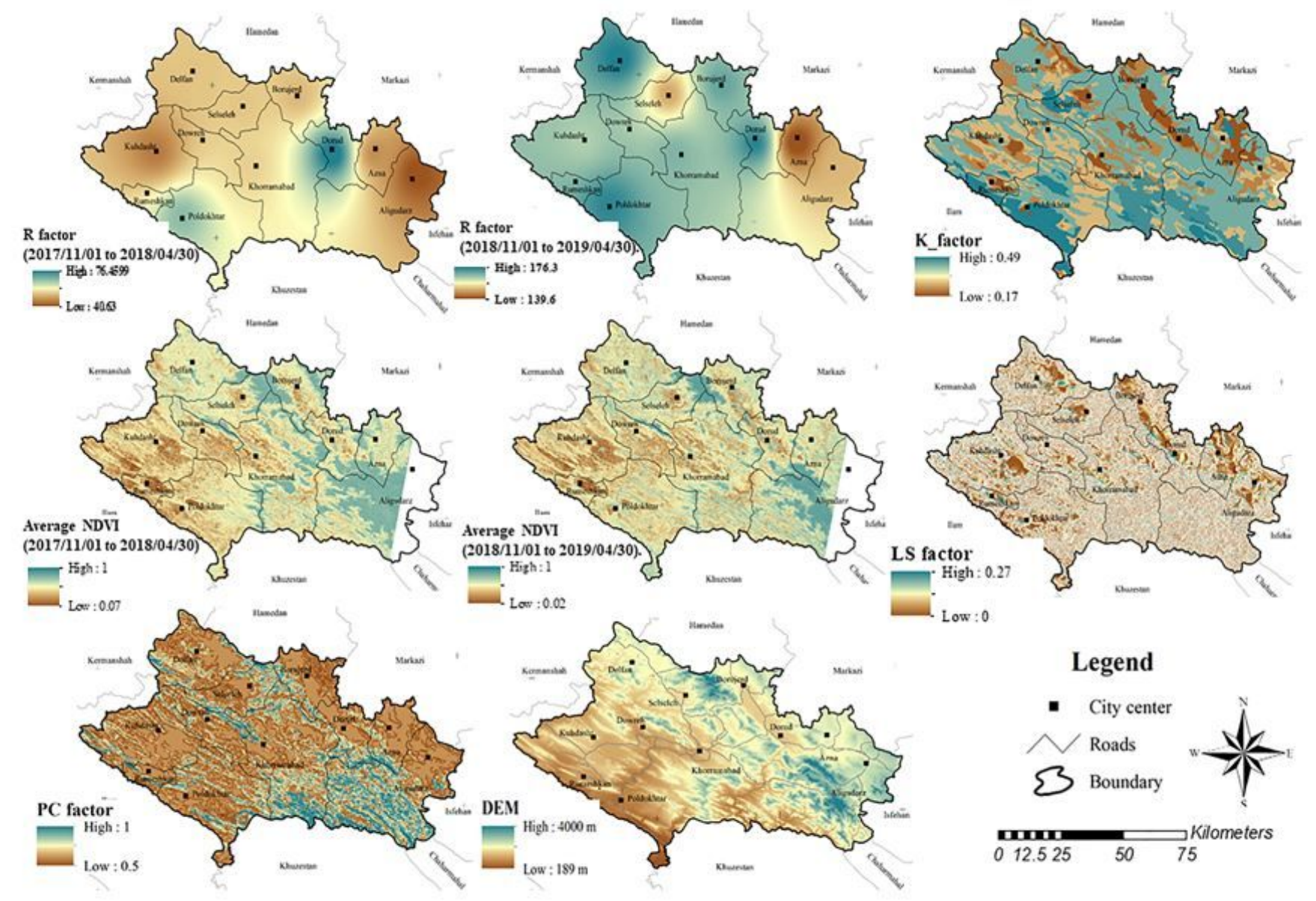

\section{Figure 3}

The data used in the RUSLE model
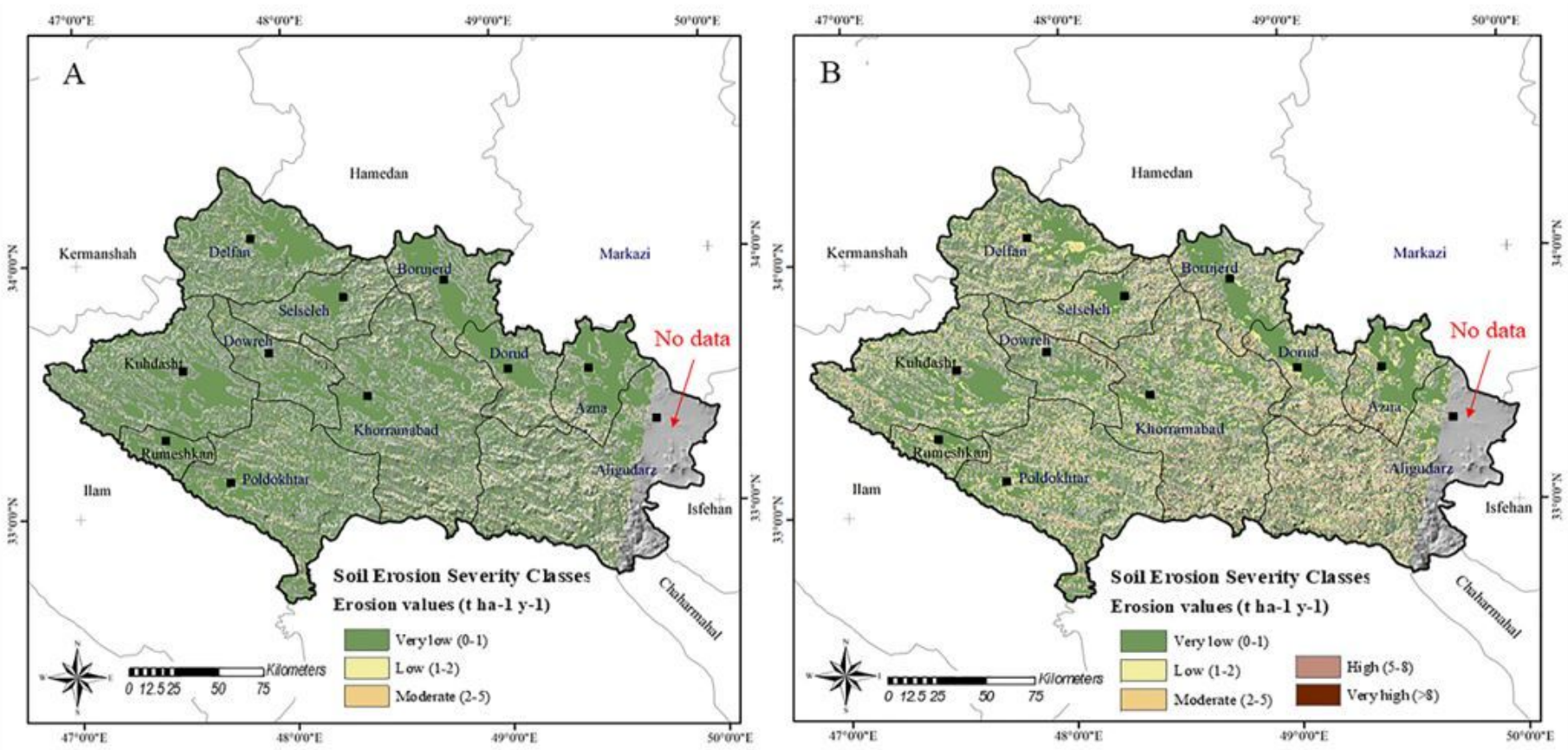

Figure 4 
The soil loss map of the study area for the period before flooding (A) and after flooding (B).
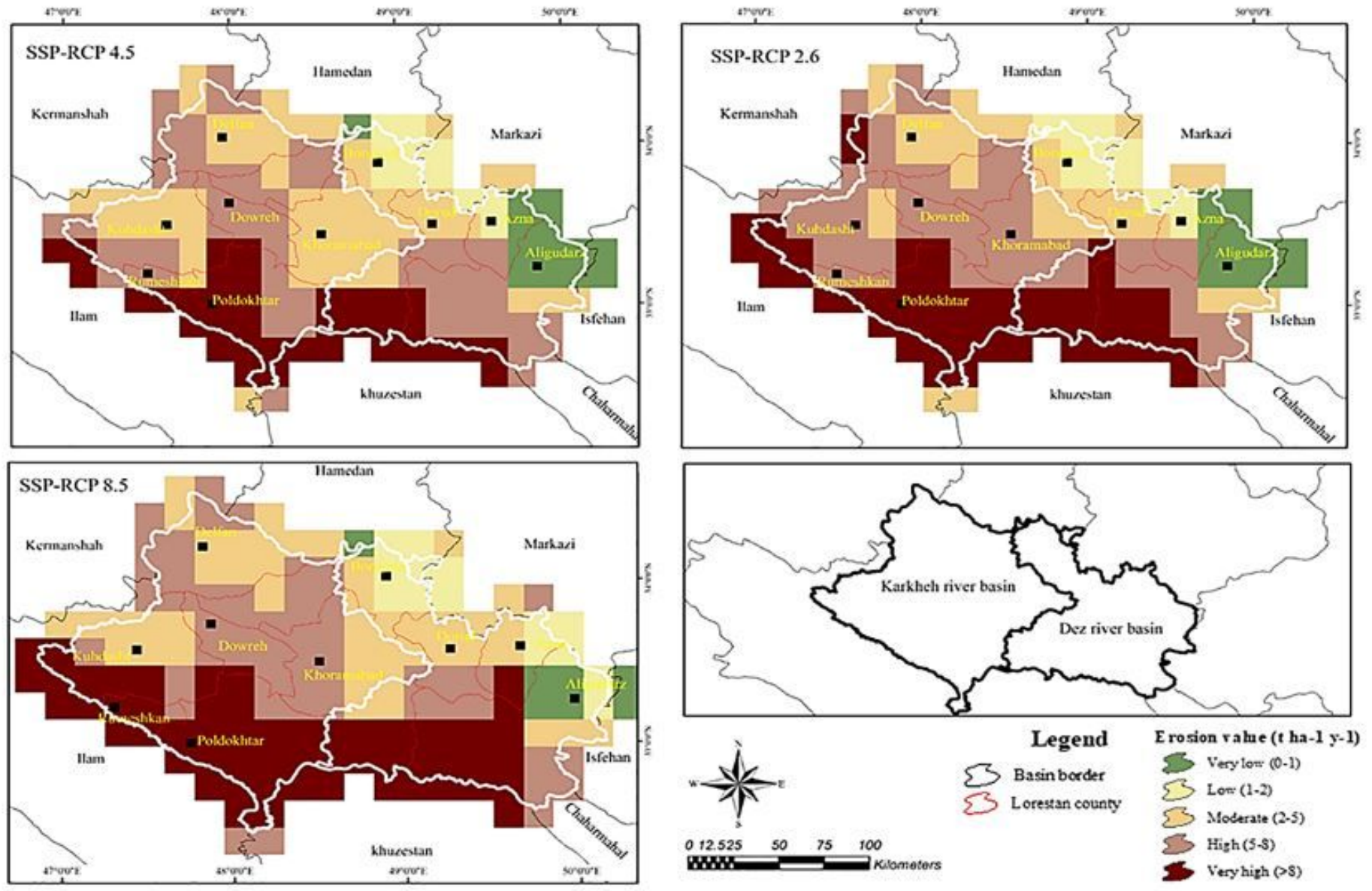

Figure 5

Soil erosion in the study area in 2070 under different climate change-land use change scenarios

\section{Supplementary Files}

This is a list of supplementary files associated with this preprint. Click to download.

- CompliancewithEthicalStandards.docx 